\title{
Sieve Plates and Habitat Adaptation in the Foraminifer Planulina ornata ${ }^{1}$
}

\author{
Jobanna M. Resig ${ }^{2}$ and Craig R. Glenn ${ }^{2}$
}

\begin{abstract}
Planulina ornata (d'Orbigny), a coarsely perforate species of foraminifera having a low trochospiral test, was recovered attached to phosphatic hardgrounds from the lower oxygen-minimum zone off Peru. Above the base of individual pores are calcified, perforate sieve plates, the largest so far described. Structure of the pores suggests a possible association with mitochondria and respiratory function. These large pores may facilitate extraction of the severely limited amount of oxygen from the ambient bottom waters at that locale.
\end{abstract}

IN THE COURSE of investigating foraminifera encrusting phosphoritic hardgrounds from the lower part of the oxygen-minimum zone of the Peru continental slope (Resig and Glenn 1997), Planulina ornata (d'Orbigny), a species in which the calcified pore plates and their perforations are unusually large, was recovered. Documentation of this occurrence is presented here to supplement the small body of literature on pore microstructure and function in foraminifera and to lend support to the proposed association of these structures with respiratory organelles (Berthold 1976, Leutenegger and Hansen 1979).

An increasing number of perforate foraminifera representing various benthic and planktonic genera are shown to have their pores closed off from the chambers by organic membranes or plates (Table 1), a condition that may exist for most perforate foraminifera (Boltovskoy and Wright 1976). The plates are reported to be nonporous in some foraminifera such as Ammonia (Banner and Williams 1973), but the majority of those studied are microporous and either calcified or not.

\footnotetext{
${ }^{1}$ Partial support of this research was provided by a National Science Foundation grant (OCE-9201305) to C.R.G. This is University of Hawai'i School of Ocean and Earth Science and Technology Contribution No. 6005. Manuscript accepted 1 March 2002.

${ }^{2}$ Department of Geology and Geophysics, University of Hawaíi at Mānoa, Honolulu, Hawai'i 96822.
}

Pacific Science (2003), vol. 57, no. 1:103-110

(C) 2003 by University of Hawai'i Press

All rights reserved
Jahn (1953) illustrated and described the microporous pore plates and termed them sieve plates. In some of the studied species, the pore plates occur singly at the base of each pore (Bé et al. 1980), but other species have multiple plates, one with each growth lamina (LeCalvez 1947, Jahn 1953, Sliter 1974). Some pore-sieve plate and micropore diameters that may be typical of finely and coarsely perforate benthic species and planktonic species are as follows: $1-\mu \mathrm{m}$ sieve plate, $0.1-\mu \mathrm{m}$ micropores in a nonionid (Jahn 1953); 2- to 6- $\mu \mathrm{m}$ sieve plate, 0.2 - to $0.3-\mu \mathrm{m}$ micropores in Lamellodiscorbis aguayoi (Arnold 1954b); and $3.3-\mu \mathrm{m}$ sieve plate, 0.1 - to $0.6-\mu \mathrm{m}$ micropores in Globigerinoides sacculifer (Bé et al. 1980). Planulina ornata, in contrast, has 6- to $10-\mu \mathrm{m}$ diameter sieve plates and 0.5 - to $1.0-\mu \mathrm{m}$ diameter micropores. These well-defined structures are presumably functional within the species' habitat.

\section{HABitat of Planulina ornata}

Planulina ornata was originally described by d'Orbigny (1839) as Truncatulina ornata from off the Port of Valparaiso, Chile, where it was rare. Its geographic range continues northward to Alaska (Buzas and Culver 1990). Specimens occur free in the sediment and are reported to be most frequent on the outer continental shelf (Bandy and Arnal 1957 [Central America], Bandy 1961 [Gulf of California]) or on the upper continental slope between 160 and $260 \mathrm{~m}$ (Boltovskoy and Theyer 1970 [Chile]). Their bathymetric range generally extends deeper along the 
TABLE 1

Reported Occurrence of Pore Plates in Foraminifera

\begin{tabular}{|c|c|}
\hline Superfamily/Species & Reference \\
\hline \multicolumn{2}{|l|}{ Spirillinacea } \\
\hline Patellina comugata & Berthold (1976) \\
\hline \multicolumn{2}{|l|}{ Nodosariacea } \\
\hline Robulus midwayensis* & Hay et al. (1963) \\
\hline \multicolumn{2}{|l|}{ Bolivinacea } \\
\hline Bolivina argentea & $\begin{array}{r}\text { Leutenegger and } \\
\text { Hansen (1979) }\end{array}$ \\
\hline Bolivina cf. excavata & $\begin{array}{r}\text { Leutenegger and } \\
\text { Hansen (1979) }\end{array}$ \\
\hline Bolivina sp. & Sliter (1974) \\
\hline "Loxostonnum" pseudobeyrichi & $\begin{array}{r}\text { Leutenegger and } \\
\text { Hansen (1979) }\end{array}$ \\
\hline \multicolumn{2}{|l|}{ Cassidulinacea } \\
\hline Cassidulinoides comuta & $\begin{array}{l}\text { Leutenegger and } \\
\text { Hansen (1979) }\end{array}$ \\
\hline \multicolumn{2}{|l|}{ Buliminacea } \\
\hline Buliminella tenuata & $\begin{array}{l}\text { Leutenegger and } \\
\text { Hansen (1979) }\end{array}$ \\
\hline Globobulimina pacifica & $\begin{array}{r}\text { Leutenegger and } \\
\text { Hansen (1979) }\end{array}$ \\
\hline \multicolumn{2}{|l|}{ Discorbacea } \\
\hline Discorbis erecta & LeCalvez (1947) \\
\hline Discorinopsis aguayoi ${ }^{* *}$ & Arnold $(1954 a, b)$ \\
\hline Rosalina floridana & Angell (1967) \\
\hline \multicolumn{2}{|l|}{ Planorbulinacea } \\
\hline Cibicides cassivellauni & $\begin{array}{l}\text { Wood and } \\
\text { Haynes (1957) }\end{array}$ \\
\hline Cymbaloporetta squammosa & $\begin{array}{l}\text { Lynts and } \\
\text { Pfister (1967) }\end{array}$ \\
\hline \multicolumn{2}{|l|}{ Asterigerinacea } \\
\hline Amphistegina madagascariensis ${ }^{* * *}$ & Hansen (1972) \\
\hline Ampbistegina lobifera & $\begin{array}{r}\text { Leutenegger and } \\
\text { Hansen }(1979)\end{array}$ \\
\hline \multicolumn{2}{|l|}{ Nonionacea } \\
\hline Nonionella stella & $\begin{array}{r}\text { Leutenegger and } \\
\text { Hansen (1979) }\end{array}$ \\
\hline Nonionidae (unspecified) & Jahn (1953) \\
\hline \multicolumn{2}{|l|}{ Rotaliacea } \\
\hline Ammonia spp. & $\begin{array}{c}\text { Banner and } \\
\text { Williams } \\
(1973)\end{array}$ \\
\hline
\end{tabular}

Nummulitacea

Nummulitidae (unspecified)

Globigerinacea

Planktonic species (unspecified)

Globigerinoides sacculifer

Globorotalia menardii western American margin, to about $1860 \mathrm{~m}$ off Chile (Ingle et al. 1980) or $1200 \mathrm{~m}$ off Peru (Resig 1981). Uchio (1960) found protoplasm-bearing tests identified through rose bengal stain from 38 to $946 \mathrm{~m}$ and empty tests from 10 to $1260 \mathrm{~m}$ off San Diego, California. Specimens are also present in Quaternary sediment of four cores from the Peruvian margin taken in water depths between 307 and $447 \mathrm{~m}$ (Resig 1990). In none of these reports did the species compose more than $4 \%$ of the benthic foraminiferal assemblages.

The extent to which sedimentary specimens reflect the life habitat of $P$. ornata is not known. Specimens found free in the sediment may have lived as epi- or infauna; they may have experienced pre- or postmortem dislodgement or transport. The adherent specimens reported here are the only ones so far to have been collected with certainty in their life positions.

Several specimens of $P$. ornata were recovered from off the coast of Peru at $11^{\circ} 59.89^{\prime}$ $\mathrm{S}, 77^{\circ} 50.91^{\prime} \mathrm{W}$ in a water depth of $517 \mathrm{~m}$, during operations of the Fobnson Sea Link I submersible (Figure 1). The specimens adhered on their umbilical sides to phosphatic crusts (samples 3363 no. 1 and no. 3) that formed in the lowermost portion of the impinging Peruvian oxygen-minimum zone, under the following oceanographic parameters: $\mathrm{O}_{2}=0.06 \mathrm{ml} /$ liter $(2.7 \mu \mathrm{M})$, temperature $=9.7^{\circ} \mathrm{C}$, and salinity $=34.7 \%$. Current velocity averaged $7 \mathrm{~cm} / \mathrm{sec}$. Large encrusting agglutinated foraminifera were dispersed over the surface of the crusts at a density of approximately 46 specimens per square centimeter on 3363 no. 3 (Resig and Glenn 1997), their food presumably drawn from benthic microbes and phytodetritus settling from the high-productivity surface waters associated with Peruvian upwelling. Of the total foraminifera occupying the habitat, less than $1 \%$ were adherent forms; the remainder were permanently affixed to the hard phosphaticcrust substrate.

The bathymetric range exhibited by $P$. ornata may relate directly to the dissolved oxygen profile off the western Americas, where oxygen depletion begins on the outer 




Figure 1. Location of samples 3363 no. 1 and no. 3 containing Planulina ormata at $11^{\circ} 59.89^{\prime} \mathrm{S}, 77^{\circ} 50.91^{\prime} \mathrm{W}$, water depth $517 \mathrm{~m}$. Oceanographic parameters as well as other samples examined from along a depth traverse are also shown. (After Resig and Glenn 1997.)

shelf (Bandy 1961, Ingle et al. 1980, Resig and Glenn 1997) and where specimens of $P$. ornata are most frequent. Bandy (1963) reported unusually large (1 to $2 \mathrm{~mm}$ diameter) specimens of the species from the bottom of three California Borderland basins with dissolved oxygen values of $0.2-0.4 \mathrm{ml} /$ liter.

\section{TEST MORPHOLOGY AND PORE MICROSTRUCTURE}

Details of the morphology of Planulina ornata are shown in Figure $2 A-M$. Planulina ornata has a compressed, keeled, trochospiral test in which the flat umbilical side is only slightly less evolute than the spiral side, which is of very low convexity (Figure $2 A-C$ ). Planoconvex shapes are considered to be advanta- geous epifaunal adaptation for attachment in turbulent water and for stability in traveling on the surface of the seafloor (Corliss 1985). The aperture, an equatorial arch at the base of the final chamber (Figure $2 A$ ), is surmounted by a lip and extends beneath an umbilical folium onto the umbilical side. Large pores are densely and evenly distributed over the chamber surfaces on both sides of the test.

The pores of $P$. ornata are 6 to $10 \mu \mathrm{m}$ in diameter and are closed by calcified sieve plates in which the micropore diameters are 0.5 to $1.0 \mu \mathrm{m}$ (Figure $2 D$ and $F$ ). Because these sieve plates are formed at the base of the pore only when a new chamber is added, they are no longer visible in the early chambers after new laminae added to the test deepen the pore canals (Figure $2 G$ ). Some of 


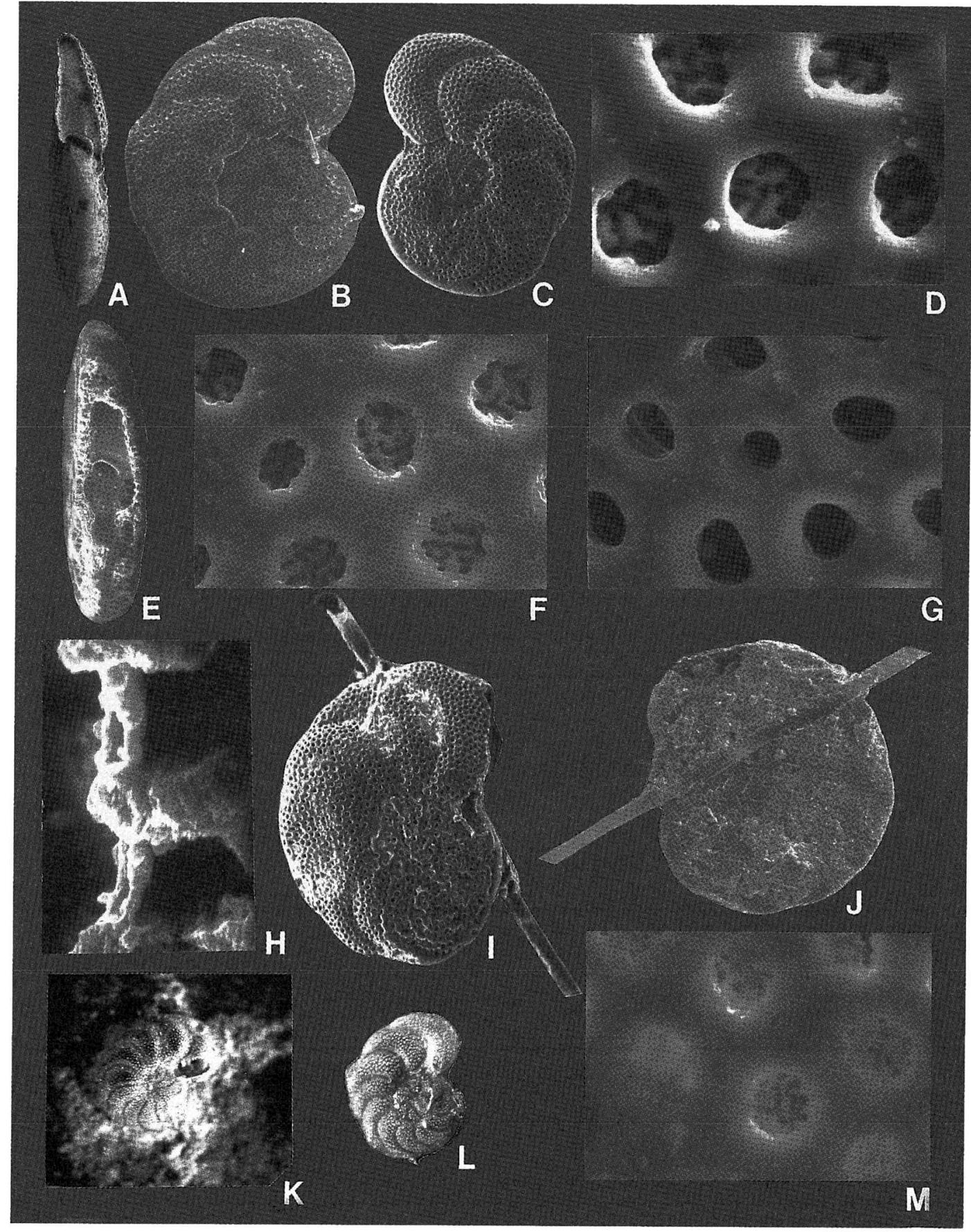


these sieve plates appear to be in direct contact with the interior, whereas others are covered by the test's organic lining (Figure $2 E, H$, and $M$ ). The absence of the lining may be an artifact of preservation or may provide some contact of the endoplasm with the test's exterior.

Orientation of the test during attachment is with the umbilical side against the hardground (Figure $2 K$ ). Because the principal opening of the aperture is peripheral, the pseudopodia would still be functional as food gatherers in this position. The umbilical extension of the aperture might allow the pseudopodia to contribute directly to test attachment, although light cementation was also noted (Figure 27). During attachment, the pores on the umbilical side appear to be sequestered from contact with the overlying water mass.

\section{PORE FUNCTION}

Test perforations are not essential to the function and well-being of foraminifera; for example, two of the principal extant groups, those with porcelaneous or agglutinated tests, are mostly without wall perforations. However, perforations have contributed to the adaptive success of the Rotaliina and their numerical superiority in all but a few modern environments, principally those habitats in which low $\mathrm{pH}$ affects the precipitation of calcium carbonate. Although originally considered as outlets for pseudopodia (Loeblich and Tappan 1964), pores have been functionally reevaluated since the discovery of pore plugs and sieve plates (LeCalvez 1947, Jahn 1953), which effectively block the passage of pseudopodia (Berthold 1976). In some instances, however, thin cytoplasmic strands have been seen to penetrate microporous sieve plates (Febvre-Chevalier 1971, Hansen 1972, Anderson and Bé 1976, Bé et al. 1980), but other plates are imperforate (Banner and Williams 1973) and impervious to such cytoplasmic interchange.

The differences in structure of the pore plates complicate the interpretation of their function or functions. Towe (1971) suggested an initial stage of chamber calcification in which the open or partially closed pores served an excretory function, and a subsequent stage of closure of the pore with an impervious organic lining. Bé et al. (1980) noted that the microporous plates penetrated by rhizopodial strands might function to transport waste in colloidal form from the test interior or for metabolic or oxygen exchange between the exterior and the cytoplasm.

Leutenegger and Hansen (1979) provided both cytological and experimental evidence regarding pore function. In fixed sections of the cells of benthic foraminifera, they found the mitochondria to be abundant and evenly distributed in the cytoplasm of species from a highly oxygenated environment, whereas a low-oxygen habitat contained species with fewer mitochondria that were clustered beneath the pore sieve plates. Mitochondria organelles are sites of major oxygen consumption as food substances are oxidized and adenosine triphosphate (ATP) is produced and distributed throughout the cell to drive

Figure 2. Planulina ornata (d'Orbigny). A, Edge view of specimen with missing ultimate chamber (umbilical side to left), foramen indicates equatorial position of lipped aperture. Diameter $0.58 \mathrm{~mm}$. JSL 3363 no. $3 . B, C, D, F, G$, Side views and pore details. $B$, Umbilical side showing extension of aperture along chamber bases. $C$, Spiral side. Maximum diameter $0.62 \mathrm{~mm}$. $D$, Enlargement of pores on ultimate chamber of spiral side showing calcareous sieve plates. Width of field $37 \mu \mathrm{m} . F$, Enlargement of pores on umbilical side showing calcareous sieve plates. Width of field $45 \mu \mathrm{m}$. $G$, Enlargement of pores on fourth chamber from last of spiral side; sieve plates have disappeared from view as pore canals deepened. Width of field $45 \mu \mathrm{m}$. JSL 3363 no. 1. E, $H$, Edge view and wall detail. $E$, Edge view of specimen with broken wall. Diameter $0.46 \mathrm{~mm} . H$, Enlargement of wall to the right of foramen showing position of sieve plate and organic lining at base of pore. Length of field $35 \mu \mathrm{m}$. KK71, GC3 (see Resig 1981). I, 7, Specimen that had been cemented to the substrate surmounting a spicule. $I$, Spiral side. $\mathcal{F}$, Umbilical side showing cement over most of surface of attachment. Maximum diameter $0.70 \mathrm{~mm}$. JSL 3363 no. 1. $K, L$, Light photographs. $K$, Specimen attached by its umbilical side to a phosphatic crust. $L$, Umbilical side of detached specimen. Maximum diameter $0.76 \mathrm{~mm}$. JSL 3363 no. 1. $M$, Enlargement of pores on interior surface of a wall fragment showing organic membrane over some pores while others remain open to the interior. Width of field $43 \mu \mathrm{m}$. KK71, GC3. 
metabolism (Hemleben et al. 1988). Leutenegger and Hansen (1979) suggested that their positioning beneath the pores leads to localized oxygen deficiency, which in turn draws in external oxygen through a diffusion gradient. In a confirming experiment, ${ }^{14} \mathrm{CO}_{2}$ uptake by symbiont-bearing Amphistegina, they demonstrated a pathway of dissolved gases through the pores.

Some of the low-oxygen species studied by Leutenegger and Hansen (1979) from 750-m water depth off Southern California also occur in muddy substrate of the oxygenminimum zone off Peru (Resig 1981). These include Buliminella tenuata, Globobulimina pacifica, and "Loxostomum" pseudobeyrichi. These species are finely perforate in contrast to the coarse perforations in $P$. ormata, and their elongate tests suggest that they are infaunal. Globobulimina pacifica does not have an organic lining that covers the pores, an adaptation that Leutenegger and Hansen attributed to low oxygen accommodation.

In $P$. ornata, the large pore diameters would provide a large surface for mitochondrial positioning, whereas the calcified sieve plate in which the micropore diameters are 0.5 to $1.0 \mu \mathrm{m}$ is a barrier to loss of these organelles, which are about $1-2 \mu \mathrm{m}$ in diameter (Hemleben et al. 1988). Large pore size, presumably to enhance respiration, also has been reported in other species in lowoxygen environments when compared with their representatives in well-oxygenated waters (Moodley and Hess 1992, Sen Gupta and Machain-Castillo 1993, Holtzmann 2000). The pores on the attachment surface of $P$. ornata are presumably sequestered from this function during test attachment, but might be in use during dislodgment or freeliving mode.

Although a respiratory function of pores fits our observations on the morphology and habitat of $P$. ornata, conflicting results concerning the distribution of mitochondria are reported by Bernhard and Alve (1996), who found them to be concentrated at the periphery of chambers "not clearly associated with pores," along the peripheral septa, and principally at the aperture in two shallowwater hyaline species, one (Stainfortbia fusi- formis) adapted to a low-oxygen environment. However, chloroplasts present in the cytoplasm of $S$. fusiformis may have played a role in its metabolism through oxygen production and thus affected the disposition of the endoplasmic mitochondria in that species. For now, the possibility that the activity of mitochondria in pseudopodia is more important than their activity associated with pores (Bernhard and Sen Gupta 1999) remains unresolved.

In $P$. ornata the broad test surface area penetrated by unusually large pores in which the sieve plates are perforated by micropores of a size precluding the passage of mitochondria strongly suggests a function related to respiration in the oxygen-starved environment to which the adherent specimens were bound. Determination of the distribution of $\mathrm{mi}^{-}$ tochondria in this species would clarify the functional morphology of the pore structure. Unfortunately, the collection of viable specimens of this relatively rare species might prove elusive.

\section{ACKNOWLEDGMENTS}

We thank the crew and scientific personnel of RV Steward Fobnson and Jobnson Sea Link I Cruise SJ 10-92 for their roles in sample and data collection, as well as two unidentified manuscript reviewers for their suggestions.

\section{Literature Cited}

Anderson, O. R., and A. W. H. Bé. 1976. The ultrastructure of a planktonic foraminifer Globigerinoides sacculifer (Brady), and its symbiotic dinoflagellates. J. Foraminiferal Res. 6:1-21.

Angell, R. W. 1967. The test structure and composition of the foraminifer Rosalina floridana. J. Protozool. 14:299-307.

Arnold, Z. 1954a. Discorinopsis aguayoi (Bermúdez) and Discorinopsis vadescens Cushman and Brönnimann: A study of variation in cultures of living foraminifera. Contrib. Cushman Found. Foraminiferal Res. 5:413.

1954b. A note on foraminiferan sieve-plates. Contrib. Cushman Found. Foraminiferal Res. 5:77. 
Bandy, O. L. 1961. Distribution of foraminifera, radiolaria, and diatoms in sediments of the Gulf of California. Micropaleontology (N.Y.) 7:1-26.

. 1963. Larger living foraminifera of the Continental Borderland of Southern California. Contrib. Cushman Found. Foraminiferal Res. 14:121-126.

Bandy, O. L., and R. E. Arnal. 1957. Distribution of Recent foraminifera off west coast of Central America. Am. Assoc. Petrol. Geol. Bull. 41:2037-2053.

Banner, F. T., and E. Williams. 1973. Test structure, organic skeleton and extrathalamous cytoplasm of Ammonia Brunnich. J. Foraminiferal Res. 3:49-69.

Bé, A. W. H., C. Hemleben, O. R. Anderson, and M. Spindler. 1980. Pore structures in planktonic foraminifera. J. Foraminiferal Res. 10:117-128.

Bernhard, J. M., and E. Alve. 1996. Survival, ATP pool, and ultrastructural characterization of benthic foraminifera from Drammensfjord (Norway): Response to anoxia. Mar. Micropaleontol. 28:5-17.

Bernhard, J. M., and B. K. Sen Gupta. 1999. Foraminifera of oxygen-depleted environments. Pages 201-216 in B. K. Sen Gupta, ed. Modern foraminifera. Kluwer Academic Publishers, Dordrecht, Netherlands.

Berthold, W.-U. 1976. Ultrastructure and function of wall perforations in Patellina corrugata Williamson, Foraminiferida. J. Foraminiferal Res. 6:22-29.

Boltovskoy, E., and F. Theyer. 1970. Foraminíferos recientes de Chile, central. Rev. Mus. Argent. Cienc. Nat. "Bernardino Rivadavia" Hidrobiol. 2:279-380, pls. 1-6.

Boltovskoy, E., and R. Wright. 1976. Recent foraminifera. W. Junk Publishers, The Hague.

Buzas, M. A., and S. J. Culver. 1990. Recent benthic foraminiferal provinces of the Pacific continental margin of North and Central America. J. Foraminiferal Res. 20:326-335.

Corliss, B. H. 1985. Microhabitats of benthic foraminifera within deep-sea sediments. Nature (Lond.) 314:435-438.

d'Orbigny, A. 1839. Voyage dans l'Amérique
Méridionale; Foraminifères. Vol. 5, pt. 5:40, pl. 6, figs. 7-9. Levrault, Strassbourg, France.

Febvre-Chevalier, C. 1971. Constitution ultrastructurale de Globigerina bulloides d'Orbigny, 1826 (Rhizopoda-Foraminifera). Protistologica 7:311-324.

Hansen, H. J. 1972. Pore pseudopodia and sieve plates of Amphistegina. Micropaleontology (N.Y.) 18:223-230.

Hay, W. W., K. M. Towe, and R. C. Wright. 1963. Ultramicrostructure of some selected foraminiferal tests. Micropaleontology (N.Y.) 9:171-195.

Hemleben, Ch., A. W. H. Bé, O. R. Anderson, and S. Tuntivate. 1977. Test morphology, organic layers and chamber formation of the planktonic foraminifer Globorotalia menardii (d'Orbigny). J. Foraminiferal Res. 7:1-25.

Hemleben, Ch., M. Spindler, and O. R. Anderson. 1988. Modern planktonic foraminifera. Springer, New York.

Holtzmann, M. 2000. Species concept in foraminifera: Ammonia as a case study. Micropaleontology (N.Y.) 46 (Suppl. 1): 21-37.

Ingle, J. C., Jr., G. Keller, and R. L. Kolpack. 1980. Benthic foraminiferal biofacies, sediments, and water masses of the southern Peru-Chile Trench area, southeastern Pacific Ocean. Micropaleontology (N.Y.) 26:113-150.

Jahn, B. 1953. Elektronenmikroskopische Untersuchungen an Foraminiferenschalen. Z. Wiss. Mikrosk. Mikrosk. Tech. 61:294297.

LeCalvez, J. 1947. Les perforations du test de Discorbis erecta (Foraminifere). Bull. Lab. Marit. Dinard 39:1-4.

Leutenegger, S., and H. J. Hansen. 1979. Ultrastructural and radiotracer studies of pore function in foraminifera. Mar. Biol. (Berl.) 54:11-16.

Loeblich, A. R., Jr., and H. Tappan. 1964. Protista 2. Sarcodina chiefly "thecamoebians" and Foraminiferida. Part C of R. C. Moore, ed. Treatise on invertebrate paleontology. Geological Society of America, New York, and University of Kansas, Lawrence. 
Lynts, G. W., and R. M. Pfister. 1967. Surface ultrastructure of some tests of Recent Foraminiferida from the Dry Tortugas, Florida. J. Protozool. 14:387-399.

Moodley, L., and C. Hess. 1992. Tolerance of infaunal benthic foraminifera for low and high oxygen concentrations. Biol. Bull. (Woods Hole) 183:94-98.

Resig, J. M. 1981. Biogeography of benthic foraminifera of the northern Nazca plate and adjacent continental margin. Geol. Soc. Am. Mem. 154:619-665. 1990. Benthic foraminiferal stratigraphy and paleoenvironments off Peru, Leg 112. Pages 263-296 in E. Suess, R. von Huene, et al., eds. Proceedings of the Ocean Drilling Program, Scientific Results, 112. Ocean Drilling Program, College Station, Texas.

Resig, J. M., and C. R. Glenn. 1997. Foraminifera encrusting phosphoritic hardgrounds of the Peruvian upwelling zone:
Taxonomy, geochemistry, and distribution. J. Foraminiferal Res. 27:133-150.

Sen Gupta, B. K., and M. L. MachainCastillo. 1993. Benthic foraminifera in oxygen-poor habitats. Mar. Micropaleontol. 20:183-201.

Sliter, W. V. 1974. Test ultrastructure of some living benthic foraminifers. Lethaia 7:5-16.

Towe, K. M. 1971. Lamellar wall construction in planktonic foraminifera. Proc. 2nd Int. Conf. Plankton Microfossils, Rome 2:1213-1224.

Uchio, T. 1960. Ecology of living benthonic foraminifera from the San Diego, California area. Cushman Found. Foraminiferal Res. Spec. Publ. 5:1-72.

Wood, A., and J. Haynes. 1957. Certain smaller British Paleocene foraminifera, Part 2. Cibicides and its allies. Contrib. Cushman Found. Foraminiferal Res. 8:4553. 